\title{
Assessing Groundwater Quality for Drinking Purpose in Jordan: Application of Water Quality Index
}

\author{
Mohamad Najib Ibrahim ${ }^{1}$ \\ 1 Department of Civil Engineering, Tafila Technical University, P.O. Box 179, Tafila 66110, Jordan \\ e-mail: m.najib@ttu.edu.jo
}

\begin{abstract}
Groundwater is a key source of drinking water in Jordan. This study was conducted to assess the suitability of groundwater in major groundwater basins in Jordan for drinking purposes. The groundwater quality data from sixteen sampling stations within one-year-monitoring period from March 2015 to February 2016 were used. Weighted arithmetic water quality index (WQI) with respect to the Jordanian standards for drinking water was used for quality assessment. Sixteen Physical, chemical and microbiological parameters were selected to calculate WQI. The result showed that all physical and chemical parameters were almost below the maximum allowable level based on the Jordanian standards for drinking. On the other hand, the microbiological parameter (i.e. E.coli count) was exceeded the maximum allowable limit in all the studied locations based on the Jordanian standards for drinking water. The computed WQI values range from 40 to 4295. Therefore, out of 16 studied locations, three locations are classified in the "Excellent water" class, nine locations as a "Good water" class, one as a "Poor water" class, two as a "very poor water" class, and one as a "water unsuitable for drinking purpose" class. Furthermore, Escherichia coli is considered the most effective parameter on the determination of WQI in this study. This result highlighted the importance of including the microbiological parameters in any drinking water assessment, since they reflect with other physical and chemical parameters the actual condition of water quality for different purposes.
\end{abstract}

Keywords: water quality index, groundwater quality, drinking water, Escherichia coli, hydrochemistry, Jordan

\section{INTRODUCTION}

Worldwide, the stress on the freshwater resources is increasing due to population growth and rapid industrialization. Groundwater is a key source of water supply in many countries. In Jordan, among different types of available water resources, groundwater provides $60 \%$ of the total supply (602 million cubic meters (MCM) out of $1008 \mathrm{MCM}$ in 2015) distributed as $332.5 \mathrm{MCM}$ for drinking and domestic uses, 237.6 MCM for Agricultural, 31 MCM for industry (MWI, 2015). The suitability of groundwater for various uses depends on its quality. Over pumping, continual and excessive abstraction associated with a low recharging rate, will eventually lead to the depletion of groundwater and deterioration of its quality (Abbasnia et al., 2018; Magesh \& Chandrasekar, 2013).Moreover, the groundwater quality is largely influenced by the natural processes and anthropogenic activities in the surrounding area (Kumar \& Chandrasekar, 2012; Nagarajan et al., 2010). Hence, to safeguard the groundwater in the region, groundwater quality monitoring and assessment are vital steps for effective water resources management.

The traditional assessment approach of groundwater quality is conducted on a parameter by parameter basis by comparing the parameter concentration value from the monitoring data with the water quality guideline value. The water samples in which the parameters concentration values exceed their limit values are expected to have health significance (Dede et al., 2013). However, this approach provides partial information on the overall quality (Pesce \& Wunderlin, 2000) and does not provide any information on the spatial and temporal trends of the overall quality (Debels 
et al., 2005; Kannel et al., 2007). Moreover, the interpretation of the results of this approach is not always an easy task. In most cases, among large number of parameters used to describe the water quality status of water body, some parameters are within the guideline limits but others are not, then the overall quality of water is ambiguous. Thus, modern approaches such as water quality indices (WQI) are suggested.

WQI is a mathematical framework used to convert large water quality data into a single number and common categorization (i.e. excellent, good, poor, very poor, and unsuitable) which represent the overall water quality level. The first WQI was proposed by Horton in 1965 (Horton, 1965 ) for drinking water supply assessments. In 1970, Brown and co-workers (Brown et al., 1970) developed the general WQI as a standard measure to compare the water quality of different water bodies. Then, a few methods were developed by several authors and organizations to calculate the WQI to evaluate both surface water and groundwater quality for different uses. These indices are different in how their sub-indices are formulated and in the aggregation process of these sub- indices to compute the final index value (Ponsadailakshmi et al., 2018; Sutadian et al., 2016). Further details on the development and application of WQIs around the world are provided in recent references such as (Abbasi \& Abbasi, 2012; Asadollahfardi, 2015; A. Lumb et al., 2012; Ashok Lumb et al., 2011; Sutadian et al., 2016).

When water is extremely limited, as is the case in Jordan, the water quality must be carefully examined to assure that the available resources are fully and efficiently utilized. Part of Jordan's water strategy and policies is to protect the groundwater resources from pollution and give priority of allocation of the groundwater resources to municipal and industrial uses (MWI, 2002). Needless to say, there is a need to evaluate the groundwater quality for drinking purposes in the Jordan on a continuous basis since it is considered as a primary source for drinking water. To the best of my knowledge, the evaluation of groundwater quality in Jordan by using water quality indices methodologies has not yet been carried out. The major objective of present study was to evaluate the suitability of groundwater in major groundwater basins in Jordan for drinking purposes based on water quality index approach. Special emphasis was placed on the assessment of the physicochemical and microbiological properties of the groundwater in major groundwater basins. A secondary objective was to identify the main parameters which may affect the groundwater quality in the each of the studied basins (i.e. the effect of the each water quality parameter on the WQI values). The results of this research will allow water managers and policy makers to interpret the groundwater quality conditions for proper actions on groundwater quality management.

\section{DATA AND METHODOLOGY}

\section{Groundwater Resources in Jordan}

There are twelve groundwater basins in Jordan (MWI/NWMP, 2004) - see Figure 1. The groundwater resources in Jordan are classified into renewable and non-renewable fossil resources. The safe yield of renewable groundwater basins in Jordan was provided by the ministry of water and irrigation as 275 million cubic meters per year ((MCM/yr) (MWI/NWMP, 2004). The actual abstraction of groundwater resources was around $625 \mathrm{MCM}$ in 2015 (MWI, 2015), out of which $480 \mathrm{MCM}$ was from renewable groundwater (175 per cent of the safe yield) and the rest (i.e. $125 \mathrm{MCM}$ ) from fossil water. The renewable groundwater resources in Jordan are concentrated mainly in the Yarmouk, Azraq, Amman-Zarqa and Dead Sea basins (El-Naqa \& Al-Shayeb, 2009). Among the twelve basins, the Disi and Jafr fossil aquifers are considered as non-renewable groundwater resources. Currently, the groundwater from Disi aquifer is transferred to Amman, the capital of Jordan, in order to supplement its domestic water needs.

In this study, sixteen sampling stations were selected for collecting the water samples from groundwater resources such as well, spring and treatment plant inlet that belong to different groundwater basins in Jordan. The details of the groundwater sampling stations are given in Table 1. These stations are part of the Ministry of Environment (MoE) national project for monitoring water quality in Jordan sampling locations (MoE, 2016).

\section{Calculation of the WQI}

In this study, the WQI for groundwater was calculated by the weighted arithmetic mean method (Brown et al., 1970) with respect to the Jordanian 


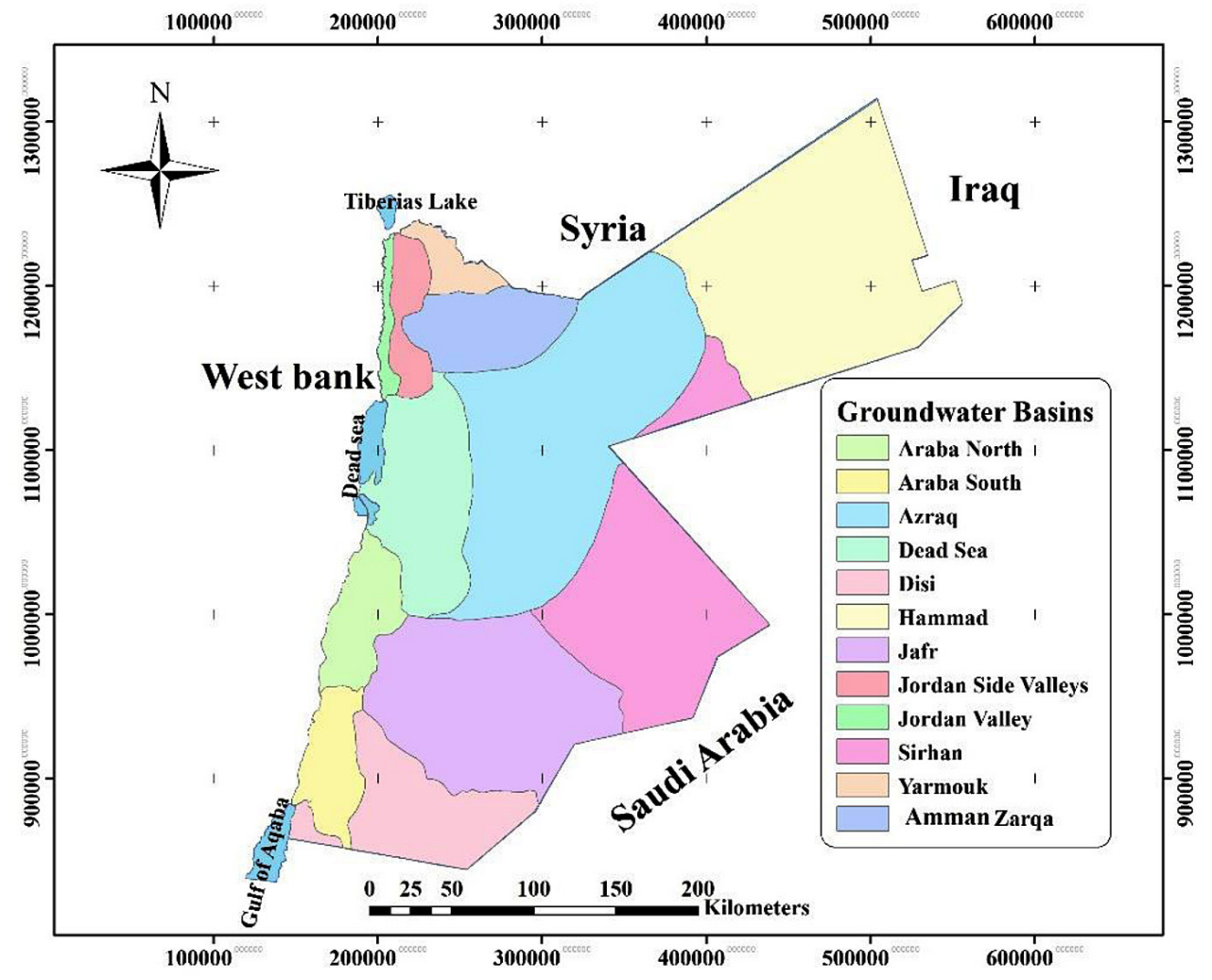

Figure 1. Groundwater Basins in Jordan

standards for drinking water (JS 286/2015), hereafter referred to as the JS286, (JS, 2015). The methodology for the calculation of WQI can be summarized in the following five steps:

\section{Parameter selection}

According to the World Health Organization (WHO), the priority parameters that should be considered in any drinking water quality assessment are those that have the greatest health impact and are most commonly detected at significant concentrations in drinking water (WHO, 2006). The microbiological parameters belong to this category classification. Thus, sixteen parameters were selected in this study to calculate WQI ( $\mathrm{pH}$, total dissolved solid (TDS), total hardness (TH), turbidity (Turb), sulphates $\left(\mathrm{SO}_{4}^{-2}\right)$, chlorides $\left(\mathrm{Cl}^{-}\right)$, nitrates $\left(\mathrm{NO}_{3}^{-}\right)$, fluorides $\left(\mathrm{F}^{-}\right)$, sodium $\left(\mathrm{Na}^{+}\right)$, copper $(\mathrm{Cu})$, zinc $(\mathrm{Zn})$, lead $(\mathrm{Pb})$, iron $(\mathrm{Fe})$, manganese $(\mathrm{Mn})$, chromium $(\mathrm{Cr})$, and Escherichia coli (E.coli).

In this study, the data set for the aforementioned parameters was obtained from the MoE monitoring program for groundwater (MoE, 2016). The groundwater samples were collected from selected locations within one-year-monitoring period from March 2015 to February 2016. All sampling steps, including samples preservation and the analysis of all parameters were carried out according to the standard methods for water and wastewater (APHA, 2005).

Table 1. Details of groundwater sampling stations.

\begin{tabular}{|c|l|l|}
\hline ID & \multicolumn{1}{|c|}{ Sampling stations } & Groundwater Basin \\
\hline S1 & Qairawan spring & Amman Zarqa \\
\hline S2 & Qunayyah spring & Amman Zarqa \\
\hline S3 & $\begin{array}{l}\text { Um Rumaneh treatment } \\
\text { (inlet) }\end{array}$ & Amman Zarqa \\
\hline S4 & Sarah spring & Dead Sea \\
\hline S5 & Wadi Es Sir spring & Dead Sea \\
\hline S6 & Bahhath spring & Dead Sea \\
\hline S7 & Ain Turab spring & Yarmouk \\
\hline S8 & Jabir Well & Yarmouk \\
\hline S9 & Muwaqqar Well & Azraq \\
\hline S10 & Bashiriyeh Well & Azraq \\
\hline S11 & Orabi Well & Azraq \\
\hline S12 & Rwaished Well & Hammad \\
\hline S13 & Tabqat Fahil spring & Jordan Valley \\
\hline S14 & Ain Dana spring & Araba North \\
\hline S15 & Al mohamadiah Well & Jafer \\
\hline S16 & Aqaba main Reservoir & Disi \\
\hline
\end{tabular}




\section{Unit weight assignment for each parameter}

First, a unit weight was assigned to each of the parameters under consideration $\left(w_{i}\right)$ according to its health effects when present in drinking water - Table 2 . The maximum weight assigned is five (the highest effect on drinking water quality) and the minimum weight assigned is one (the least effect on drinking water quality). Then, the relative weight for each parameter (Wi) is calculated by dividing its unit weight by the sum of unit weight of all parameters as per the following formula:

$$
W_{i}=\frac{w_{i}}{\sum_{i=1}^{n} w_{i}}
$$

where: $W_{i}$ is the relative weight,

$w_{i}$ is the unit weight of each parameter and

$n$ is the number of selected parameters ( $n$

$=16$ in this study).

\section{Calculation of the rating scale for each parameter}

Rating scale transforms the different units and dimensions of water quality parameters to common scale. The rating scale $\left(Q_{i}\right)$ for each parameter is calculated by dividing its concentration by its permissible limit value as defined in JS286 and the result multiplied by 100 according to the following equation:

$$
Q_{i}=\left(\frac{C_{i}-I_{i}}{S_{i}-I_{i}}\right) \times 100
$$

where: $Q_{i}$ is the rating scale,
$C_{i}$ is the concentration corresponding to $i^{\text {th }}$ parameter in $\mathrm{mg} / \mathrm{L}$ at a given sampling location,

$I_{i}$ is the ideal value of $i^{\text {th }}$ parameter in pure water (i.e., The ideal value for $\mathrm{pH}=7$, and equal to zero for all other parameters), and

$S_{i}$ is the drinking water standard for $i^{\text {th }}$ parameter in $\mathrm{mg} / \mathrm{L}$ according to the JS286.

\section{Developing sub-indices}

The water quality sub-index value $\left(S I_{i}\right)$ is determined for each parameter by multiplying its relative weight $(\mathrm{Wi})$ with its rating scale $\left(Q_{i}\right)$ as follows

$$
S I_{i}=W_{i} \times Q_{i}
$$

where: $S I_{i}$ is the sub-index value for $i^{\text {th }}$ parameter.

\section{Aggregation of sub-indices}

In this study, additive aggregation is applied to obtain the water quality index (WQI). Thus, the WQI is the sum of sub-indices of all selected parameters as per the following equation:

$$
W Q I=\sum_{i=1}^{n} S I_{i}
$$

The groundwater quality types were determined according to the computed WQI values. These types were classified into five categories

\begin{tabular}{|c|c|c|c|}
\hline Parameters & Unit weight & Relative weight & JS 286/2015 Standard ${ }^{a}$ \\
\hline $\mathrm{pH}$ & 4 & 0.064 & $6.5-8.5$ \\
\hline Total dissolved solid (TDS), mg/L & 4 & 0.064 & $1000-1300$ \\
\hline Total hardness $(\mathrm{TH})$ as $\mathrm{CaCO}_{3}, \mathrm{mg} / \mathrm{L}$ & 3 & 0.048 & $500-600$ \\
\hline Turbidity (Turb), NTUa & 3 & 0.048 & 5 \\
\hline Sulphates $\left(\mathrm{SO}_{4}^{-2}\right), \mathrm{mg} / \mathrm{L}$ & 5 & 0.079 & $200-500$ \\
\hline Chlorides $\left(\mathrm{Cl}^{-}\right), \mathrm{mg} / \mathrm{L}$ & 5 & 0.079 & $200-500$ \\
\hline Nitrates $\left(\mathrm{NO}_{3}^{-}\right), \mathrm{mg} / \mathrm{L}$ & 5 & 0.079 & $50-70$ \\
\hline Fluorides $\left(\mathrm{F}^{-}\right), \mathrm{mg} / \mathrm{L}$ & 5 & 0.079 & $1.5-2$ \\
\hline Sodium $\left(\mathrm{Na}^{+}\right), \mathrm{mg} / \mathrm{L}$ & 3 & 0.048 & $200-300$ \\
\hline Copper (Cu) , mg/L & 2 & 0.032 & 2 \\
\hline Zinc $(Z n), \mathrm{mg} / \mathrm{L}$ & 2 & 0.032 & 4 \\
\hline Lead $(\mathrm{Pb}), \mathrm{mg} / \mathrm{L}$ & 5 & 0.079 & 0.01 \\
\hline Iron $(\mathrm{Fe}), \mathrm{mg} / \mathrm{L}$ & 3 & 0.048 & 1 \\
\hline Manganese $(\mathrm{Mn}), \mathrm{mg} / \mathrm{L}$ & 4 & 0.064 & 0.4 \\
\hline Chromium (Cr), mg/L & 5 & 0.079 & 0.05 \\
\hline Escherichia coli (E.coli), MPN//100 mL & 5 & 0.079 & 1.1 \\
\hline
\end{tabular}
(Sahu \& Sikdar, 2008), as shown in Table 3.

Table 2. The unit weight and relative weight of each parameters used for WQI computation with Jordanian standard for drinking water quality 


\section{Effective weight calculation}

In order to accomplish the second objective, the effect of the each water quality parameter on the WQI values was calculated by its effective weight. The effective weight $\left(E W_{i}\right)$ for each parameter was determined by dividing its sub-index value $\left(S I_{i}\right)$ by the WQI value at a given sampling location and the result was multiplied by 100 as in the following equations (Şener et al., 2017):

$$
E W_{i}=\frac{S I_{i}}{W Q I} \times 100
$$

where: $E W_{i}$ is the effective weight value for $i^{\text {th }}$ parameter.

\section{RESULTS AND DISCUSSION}

\section{General characteristics of groundwater resources quality in Jordan}

The mean values of the monitoring period for each measured groundwater quality parameter used in this study at each sampling location are presented in Table 4, with minimum and maximum values among these sampling locations. The $\mathrm{pH}$ values ranged from 7.15 to 8.71 which indicates
Table 3. The WQI range and water quality classification for drinking purposes

\begin{tabular}{|c|c|}
\hline WQI range & Type of water \\
\hline$<50$ & Excellent water \\
\hline $50-100$ & Good water \\
\hline $100.1-200$ & Poor water \\
\hline $200.1-300$ & Very poor water \\
\hline$>300$ & Water unsuitable for drinking \\
\hline
\end{tabular}

the slightly alkaline nature of groundwater in all studied locations. As per the JS286, all values fall within the permissible limits (6.5 to 8.5$)$, except for the sample location S10 (i.e. Bashiriyeh Well) in Azraq basin where the mean pH value is 8.71. The alkaline nature of groundwater is mainly caused by bicarbonate concentration in the water aquifers. The $\mathrm{pH}$ of water is important because it controls many of the geochemical reactions or solubility calculations within groundwater. Moreover, $\mathrm{pH}$ is an important operational parameter in treatment plant. The $\mathrm{pH}$ must be controlled within a favorable range for chemical processes in coagulation, disinfection, softening and corrosion control. Failure to minimize corrosion (corrosion occur at low $\mathrm{pH}$ ) can result in the contamination of drinking water and aesthetic problems.

Table 4. Measured groundwater quality parameters used in this study at each sampling location, data represents the mean values a of the monitoring period. The minimum and maximum values are among the sampling locations

\begin{tabular}{|c|c|c|c|c|c|c|c|c|c|c|c|c|c|c|c|c|c|c|}
\hline $\begin{array}{l}\text { ara- } \\
\text { eters }\end{array}$ & S1 & S2 & S3 & S4 & S5 & S6 & S7 & S8 & S9 & S10 & S11 & S12 & S13 & S14 & S15 & S16 & Max & Min \\
\hline $\mathrm{pH}$ & 7.15 & 7.43 & 7.4 & 7.81 & 7.29 & 7.4 & 7.84 & 7.78 & 7.48 & 8.71 & 7.96 & 7.28 & 7.24 & 7.82 & 7.63 & .61 & 3.71 & 7.15 \\
\hline TDS & 446 & 424 & 671 & 429 & 454 & 438 & 329 & 464 & 424 & 262 & 680 & 1417 & 565 & 391 & 337 & 194 & 1417 & 194 \\
\hline TH & 424 & 376 & 470 & 263 & 407 & 308 & 218 & 236 & 290 & 23 & 283 & 861 & 506 & 289 & 267 & 118 & 861 & 23 \\
\hline Turb & 0.3 & 0.1 & 0.2 & 0.45 & 0.7 & 0.55 & 0.08 & 0.4 & 0.25 & 0.45 & 0.23 & 4.8 & 0.1 & 0.1 & 0.75 & 0.05 & 4.8 & 0.05 \\
\hline $\mathrm{SO}_{4}^{-2}$ & 28 & 35 & 53 & 36 & 32 & 35 & 9 & 37 & 60 & 42 & 37 & 605 & 67 & 16 & 39 & 18.9 & 605 & 9 \\
\hline $\mathrm{Cl}^{-}$ & 53 & 70 & 160 & 68 & 83 & 74 & 24 & 134 & 115 & 47 & 249 & 187 & 132 & 59 & 54 & 37 & 249 & 24 \\
\hline $\mathrm{NO}_{3}^{-}$ & 45 & 61 & 33 & 46 & 36 & 38 & 22 & 2.3 & 1 & 7.3 & 22 & 1 & 16 & 17 & 1.9 & 8.18 & 61 & 1 \\
\hline $\mathrm{F}^{-}$ & 0.229 & 0.364 & 0.486 & 0.411 & 0.304 & 0.338 & 0.306 & 0.709 & 1.9 & 0.124 & 0.332 & 1.523 & 0.341 & 0.256 & 0.901 & 0.222 & 1.9 & 0.124 \\
\hline $\mathrm{Na}^{+}$ & 25 & 41 & 99 & 30 & 36 & 32 & 14 & 94 & 52 & 80 & 112 & 145 & 73 & 20 & 23 & 21 & 145 & 14 \\
\hline u & 0.02 & 0.02 & 0.02 & 0.02 & 02 & 0.02 & .02 & 0.02 & 0.02 & 0.02 & .02 & $\begin{array}{l}< \\
02\end{array}$ & $\begin{array}{c}< \\
0.02\end{array}$ & $\begin{array}{c}< \\
0.02\end{array}$ & \begin{tabular}{|c|}
$<<$ \\
0.02
\end{tabular} & 0.02 & $\begin{array}{c}<< \\
0.02\end{array}$ & 0.02 \\
\hline $\mathrm{Zn}$ & 0.1 & 0.016 & 0.016 & 0.03 & 0.016 & 0.03 & 0.016 & 0.016 & .016 & 0.016 & 0.016 & 0.06 & 0.016 & 0.016 & 0.016 & 0.016 & 0.1 & 0.016 \\
\hline $\mathrm{Pb}$ & $\begin{array}{c}< \\
0.01\end{array}$ & $\begin{array}{c}< \\
0.01\end{array}$ & $\begin{array}{c}<< \\
0.01\end{array}$ & \begin{tabular}{|c|}
$<$ \\
0.01
\end{tabular} & $\begin{array}{c}< \\
0.01\end{array}$ & $\begin{array}{c}<< \\
0.01\end{array}$ & $\begin{array}{l}< \\
.01\end{array}$ & $\begin{array}{l}< \\
.01\end{array}$ & $\begin{array}{l}< \\
.01\end{array}$ & $\begin{array}{c}<< \\
0.01\end{array}$ & $\begin{array}{l}< \\
.01\end{array}$ & $\begin{array}{l}< \\
.01\end{array}$ & $\begin{array}{l}< \\
.01\end{array}$ & $\begin{array}{l}< \\
.01\end{array}$ & $\begin{array}{l}< \\
.01\end{array}$ & $\begin{array}{l}< \\
.01\end{array}$ & $\begin{array}{l}< \\
.01\end{array}$ & $\begin{array}{l}< \\
.01\end{array}$ \\
\hline $\mathrm{Fe}$ & 0.04 & 0.04 & 0.04 & 0.04 & \begin{tabular}{|l|l|}
0.04 \\
\end{tabular} & 0.04 & 0.04 & 0.09 & \begin{tabular}{|l|l|}
0.04 \\
\end{tabular} & 0.1 & 0.04 & 0.11 & 0.04 & 0.04 & \begin{tabular}{|l|l|}
0.04 \\
\end{tabular} & 0.04 & 0.11 & 0.04 \\
\hline $\mathrm{Mn}$ & $\begin{array}{c}< \\
0.017\end{array}$ & $\begin{array}{c}< \\
0.017\end{array}$ & $\begin{array}{c}< \\
0.017\end{array}$ & $\begin{array}{c}< \\
0.017\end{array}$ & $\begin{array}{c}< \\
0.017\end{array}$ & $\begin{array}{c}< \\
0.017\end{array}$ & $\begin{array}{c}< \\
0.017\end{array}$ & $\begin{array}{c}< \\
0.017\end{array}$ & $\begin{array}{c}<< \\
0.017\end{array}$ & $\begin{array}{c}<< \\
0.017\end{array}$ & $\begin{array}{c}< \\
0.017\end{array}$ & $\begin{array}{c}<< \\
0.017\end{array}$ & $\begin{array}{c}< \\
0.017\end{array}$ & $\begin{array}{c}<< \\
0.017\end{array}$ & $\begin{array}{c}<< \\
0.017\end{array}$ & $\begin{array}{c}<< \\
0.017\end{array}$ & $\begin{array}{c}< \\
0.017\end{array}$ & $\begin{array}{c}< \\
0.017\end{array}$ \\
\hline $\mathrm{Cr}$ & $\begin{array}{c}< \\
0.05\end{array}$ & $\begin{array}{c}< \\
0.05\end{array}$ & 0.05 & $\begin{array}{l}< \\
0.05\end{array}$ & $\begin{array}{c}< \\
0.05\end{array}$ & $\begin{array}{l}< \\
0.05\end{array}$ & $\begin{array}{c}< \\
0.05\end{array}$ & $\begin{array}{c}< \\
0.05\end{array}$ & 0.05 & $\begin{array}{c}< \\
0.05\end{array}$ & $\begin{array}{l}< \\
0.05\end{array}$ & $\begin{array}{c}< \\
0.05\end{array}$ & $\begin{array}{l}< \\
0.05\end{array}$ & $\begin{array}{c}< \\
0.05\end{array}$ & $\begin{array}{c}< \\
0.05\end{array}$ & $\begin{array}{c}< \\
0.05\end{array}$ & \begin{tabular}{|c|}
$<$ \\
0.05
\end{tabular} & $\begin{array}{c}< \\
0.05\end{array}$ \\
\hline E.coli & 33 & 34 & 9.4 & 3.7 & 590 & 6.4 & 1.8 & 1.8 & 1.8 & 1.8 & 1.8 & 1.8 & 1.9 & 3.7 & 6.4 & 1.9 & 590 & 1.8 \\
\hline
\end{tabular}

Note: The mean is the arithmetic mean for all parameters except for E. coli geometric mean.

All values in $\mathrm{mg} / \mathrm{l}$ except $\mathrm{TH}$ in $\mathrm{mg} / \mathrm{L}$ as $\mathrm{CaCO}_{3}$ and E.coli in MPN/100 mL.

Reference: National Project for Monitoring Water Quality in Jordan: Annual report 2015-2016 (MoE, 2016). 
The presence of dissolved solids in water may impair its taste. According to JS286, Total dissolved solid (TDS) up to $1000 \mathrm{mg} / \mathrm{L}$ is the maximum allowable limit and up to $1300 \mathrm{mg} / \mathrm{L}$ is the maximum allowable limit in case there is no water resource with a better quality, and with the approval of the Ministry of Health in Jordan. In all the studied locations, the TDS value varies in the range 194 to $1417 \mathrm{mg} / \mathrm{L}$. All of the TDS values are well below the allowable limit of $1000 \mathrm{mg} / \mathrm{L}$, except the sample location S12 (i.e. Rwaished Well) in Hammad basin where the TDS concentration is $1417 \mathrm{mg} / \mathrm{L}$. The groundwater in the sample location S12 (Rwaished Well) falls under brackish type of water (TDS $>1000 \mathrm{mg} / \mathrm{L}$ ) as per TDS classification proposed by freeze and cherry (Freeze \& Cherry, 1979). The other 15 sample locations are classified as fresh water type (TDS $<1000 \mathrm{mg} / \mathrm{L}$ ). Moreover, the palatability of drinking water can be classified according to TDS as excellent $(<300 \mathrm{mg} / \mathrm{L})$, good $(300-600 \mathrm{mg} / \mathrm{L})$, fair $(600-900 \mathrm{mg} / \mathrm{L})$, poor $(900-1200 \mathrm{mg} / \mathrm{L})$ and unacceptable (> $1200 \mathrm{mg} / \mathrm{L})(\mathrm{WHO}, 1996)$. According to this categorization, most of the studied locations (11 out of 16) fall under the good water class. On the other hand, a small number of studied locations can be classified excellent, fair and unacceptable water $(2,2$ and 1 locations, respectively).

Hardness of groundwater results mainly from presence of alkaline earth metals calcium and magnesium. The total hardness $(\mathrm{TH})$ as $\mathrm{CaCO}_{3}$ of the groundwater samples in the studied locations ranges from 23 to $861 \mathrm{mg} / \mathrm{L}$. Out of the 16 groundwater sampling locations, two locations, namely S13 (Tabqat Fahil spring) and S12 (Rwaished Well) have a TH exceeding the permissible limit of $500 \mathrm{mg} / \mathrm{L}$ as $\mathrm{CaCO}_{3}$ as per the JS286 (i.e. TH of 861 and $506 \mathrm{mg} / \mathrm{L}$ as $\mathrm{CaCO}_{3}$, respectively). Sawyer et al. (Sawyer et al., 2003) classified groundwater according to $\mathrm{TH}$ as soft ( $\mathrm{TH}<75)$, moderately hard $(75<\mathrm{TH}<150)$, hard $(150<\mathrm{TH}<300)$ and very hard $(\mathrm{TH}>300)$. Adopting these classification criteria, the groundwater of the majority of the studied locations is hard to very hard water. Out of the 16 sampling locations, seven locations belong to hard water, seven locations belong to very hard water, only one location belongs to soft water and also only one location belongs to moderately hard water. Hard water is not a health concern below the permissible level, but may affect the acceptability of drinking water (WHO, 2011a). Hard water can be a nuisance within the home. TH greater than $80 \mathrm{mg} / \mathrm{L}$ cannot be used for domestic purposes, because it coagulates soap lather (Sujatha \& Reddy, 2003). Additionally, hard water can cause scale deposition in the water distribution system, as well as in heated water applications (WHO, 2011b).

High quality drinking water should have a low level of turbidity. JS286 suggests that turbidity of less than $5 \mathrm{NTU}$ as the maximum allowable limit for drinking water. None of the sampling locations exceed this limit with turbidity value varies in the range $0.05-4.8 \mathrm{NTU}$. The turbidity value in most of the studied locations ( 15 out of 16) is less than 1 NTU. The level of turbidity in drinking water is important for aesthetic reasons and also for treatment plant operation where excessive turbidity can protect pathogenic microorganisms from the effects of disinfectants and filtration of water becomes more difficult and costly.

Sulphate ion $\left(\mathrm{SO}_{4}^{-2}\right)$ is among the major anions commonly found in fresh water resources. The sulphate concentration in the studied locations ranges between 9 and $605 \mathrm{mg} / \mathrm{L}$. These were within the maximum allowable limit $(200 \mathrm{mg} / \mathrm{L}$ and $500 \mathrm{mg} / \mathrm{L}$ in case there is no water resource with a better quality and with the approval of the Ministry of Health in Jordan) in JS286 except the sample location S12 (i.e. Rwaished Well) in Hammad basin where the sulphate concentration is $605 \mathrm{mg} / \mathrm{L}$. Moreover, the sulphate value in most of the studied locations ( 15 out of 16 ) is less than $60 \mathrm{mg} / \mathrm{L}$. Sulphate is not a health concern below the maximum allowable limit for drinking water (WHO, 2011a) but may have a laxative effect at high level, which can lead to intestinal discomfort and consequently dehydration.

In the studied locations, the chloride ion $\left(\mathrm{Cl}^{-}\right)$ value is between 24 and $249 \mathrm{mg} / \mathrm{L}$. The maximum allowable limit of chloride for drinking water is specified as $200 \mathrm{mg} / \mathrm{L}$ and 500 in case there is no water resource with a better quality, and with the approval of the Ministry of Health in Jordan as per JS286. All of the chloride values fall within the allowable limit except one sampling location S11 (i.e. Orabi Well) in Azraq basin where the chloride concentration is $249 \mathrm{mg} / \mathrm{L}$. A relatively high concentration of chloride is observed at sampling location S3 (i.e. Um Rumaneh treatment (inlet)) in Amman Zarqa basin and sampling location S12 (i.e. Rwaished Well) in Hammad basin where the chloride concentrations are 160 and $187 \mathrm{mg} / \mathrm{L}$, respectively. In reasonable concentrations, chloride is not harmful to humans. 
However, at the concentrations above $250 \mathrm{mg} / \mathrm{L}$ it gives a salty taste to water (WHO, 2011a), which is distasteful to many people. Moreover, excessive chloride concentrations can affect the corrosion of metals in the water distribution system pipes and may increase the metals concentrations in the drinking water (WHO, 2011a). Moreover, the excess of chloride in the groundwater is usually taken as an index of groundwater contamination (Loizidou \& Kapetanios, 1993).

The nitrates $\left(\mathrm{NO}_{3}^{-}\right)$concentration varies from 1 to $61 \mathrm{mg} / \mathrm{L}$ in the studied locations. Only in one sampling lactation, namely S2 (i.e. Qunayyah spring) in Amman Zarqa basin the nitrate concentration exceeds maximum allowable limit of $50 \mathrm{mg} / \mathrm{L}$ but is still below $70 \mathrm{mg} / \mathrm{L}$ that represents the maximum allowable limit in case there is no water resource with a better quality, and with the approval of the Ministry of Health in Jordan as per the JS286. Relatively high concentration of nitrate is observed at Amman Zarqa and Dead Sea groundwater basins sampling locations. The concentration of nitrate in the remaining groundwater basins is found below the allowable limit of $50 \mathrm{mg} / \mathrm{L}$. The nitrate level above the maximum allowable limit of $50 \mathrm{mg} / \mathrm{L}$ is a potential health concern, since it may cause methemoglobinemia in infants (WHO, 2011a).

Fluoride $\left(\mathrm{F}^{-}\right)$at low concentration in drinking water has been considered beneficial since it provides protection against dental caries for both children and adults. However, elevated fluoride intake causes dental fluorosis (tooth discoloration and/or pitting) and more seriously skeletal fluorosis (with adverse changes in bone structure) (WHO, 2011a). As per the JS286, the maximum allowable limit of fluoride for drinking water is specified as $1.5 \mathrm{mg} / \mathrm{L}$ and $2 \mathrm{mg} / \mathrm{L}$ in case there is no water resource with a better quality, and with the approval of the Ministry of Health in Jordan. The fluoride content in the groundwater in the studied location shows a range of 0.12 to $1.9 \mathrm{mg} / \mathrm{L}$. The fluoride concentration in groundwater of the studied locations exceeds the maximum allowable limit of $1.5 \mathrm{mg} / \mathrm{L}$ only at two locations ( $\mathrm{S} 9$ and $\mathrm{S} 12$ ) but is still below $2 \mathrm{mg} / \mathrm{L}$ that represents the maximum allowable limit in case there is no water resource with a better quality, and with the approval of the Ministry of Health in Jordan. In the studied locations, chloride is the most dominant anion in most sampling locations, followed by sulphate, nitrate and fluoride.
Sodium ion $\left(\mathrm{Na}^{+}\right)$is among the major cations and is present in most of the natural waters resources. The JS286 specifies $200 \mathrm{mg} / \mathrm{L}$ for sodium as the maximum allowable limit for drinking water and $300 \mathrm{mg} / \mathrm{L}$ in case there is no water resource with a better quality. None of the sampling locations exceed these limits with sodium value varying in the range from 14 to $145 \mathrm{mg} / \mathrm{L}$. The sodium value in most of studied locations is well below the maximum permissible limit. The level of sodium in drinking water is important for the aesthetic considerations rather than health hazard. The sodium concentrations above $200 \mathrm{mg} / \mathrm{L}$ will make the water taste salty (WHO, 2011a) while high sodium intake can have adverse effects on the humans with high blood pressure.

In the studied locations, the heavy metals copper $(\mathrm{Cu})$, zinc $(\mathrm{Zn})$, lead $(\mathrm{Pb})$, iron $(\mathrm{Fe})$, manganese $(\mathrm{Mn})$ and chromium $(\mathrm{Cr})$ concentrations are found to be less than $0.02 \mathrm{mg} / \mathrm{L}$, in the range from 0.016 to $0.1 \mathrm{mg} / \mathrm{L}$, less than $0.01 \mathrm{mg} / \mathrm{L}$, less than $0.02 \mathrm{mg} / \mathrm{L}$, in the range from 0.04 to $0.11 \mathrm{mg} / \mathrm{L}$, less than $0.017 \mathrm{mg} / \mathrm{L}$, less than $0.05 \mathrm{mg} / \mathrm{L}$, respectively. These heavy metals values are below the maximum allowable limits prescribed by the JS286, Table 2. The concentration of heavy metals followed a descending order: $\mathrm{Fe}>\mathrm{Zn}>\mathrm{Cr}>$ $\mathrm{Cu}>\mathrm{Mn}>\mathrm{Pb}$ (According to their maximum values among the studied locations). However, the presence of heavy metals in drinking water is a threat to human health considering their strong toxicity even at very low concentration. The toxicity level and the adverse effect depend on the heavy metal species. The adverse effects of heavy metals include reduced growth and development, nervous system damage, development of autoimmunity and liver or kidney damage. Few heavy metals can bioaccumulate in the human body (e.g., in lipids and the gastrointestinal system) and may induce cancer (Chowdhury et al., 2016). At higher doses, heavy metals can cause irreversible brain damage and in extreme cases, death (Barakat, 2011).

Escherichia coli (or simply E. coli) is a facultative anaerobe, gram-negative rod bacteria that lives in the intestinal tracts of warm-blooded animals. E. coli is used as an indicator of biological contamination and to verify water quality. Detection of E.coli in drinking water indicates the water has been contaminated with fecal material that may contain pathogens (i.e. disease causing microorganisms such as certain type of bacteria, viruses and protozoa). Pathogens can cause a 
range of diseases, involving the nausea, vomiting, diarrhea cholera, typhoid, viral hepatitis A and dysentery. These diseases are of special concern for infants and elderly. In extreme cases, some pathogens may infect the lungs, skin, eyes, nervous system, kidneys, or liver and the effects may lead to death (WHO, 2011a). The JS286 for E.coli bacteria allows the most probable number (MPN) of 1.1 per $100 \mathrm{~mL}$. The E.coli count exceeded this maximum allowable limit in all the studied locations. Out of the 16 studied locations, the mean E.coli counts at 15 sampling locations are in the range from 1.8 to 34 MPN per $100 \mathrm{~mL}$ and one sampling location, namely S5 (i.e. Wadi Es Sir spring) in Dead Sea basin showed a noticeable level of E.coli count of 590 MPN per $100 \mathrm{~mL}$. Thus, from the microbiological perspective, the water is not safe for drinking use and needs some degree of treatment before consumption.

\section{Assessment of the groundwater quality using WQI}

During study period, the WQI values in the studied locations are presented in Table 5. The computed WQI values range from 40 to 4295 . Consequently, the groundwater quality of the studied locations is in the "Excellent" to "Water unsuitable for drinking" range. The results from Table 5 revealed that out of 16 studied locations, three locations are classified in the "Excellent water" class, nine locations as a "Good water" class, one as a "Poor water" class, two as a "very poor water" class, and one as a "water unsuitable for drinking purpose" class.

Water unsuitable for drinking purpose has been observed in the S5 sampling location (i.e. Wadi Es Sir spring) in Dead Sea basin. This may be due to various anthropogenic activities occurring in the surrounding area, such as industrial activities and the effluent of the Wadi Es Sir wastewater treatment plant. Very poor water and poor water were observed in the sampling locations within Amman Zarqa basin. S1 and S2 are classified as very poor water and S3 is classified as poor water. This reflects the presence of anthropogenic pollution sources within the basin. The Amman Zarqa basin contains most of the Jordan commercial and industrial activities in addition to the As Samra wastewater treatment plant that treats more than 70 percent of all wastewater produced in Jordan.

The effective weight values of the each water quality parameter are obtained by Equation (5).
The summary statistics (maximum, minimum, mean and standard deviations) of the effective weight values of the each water quality parameter in all studied locations are present in Table 6. Among the selected water quality parameters, E. coli, $\mathrm{Cr}$ and $\mathrm{Pb}$ exhibit the largest mean effective weight values compared to the other parameters with effective weight of $45.65 \%, 11.16 \%$ and $11.16 \%$, respectively. Thus, these parameters are considered as the most effective parameters in the WQI values, even though the relative weight of these three parameters is equal with value of

Table 5. Results of water quality index for drinking purposes of the studied groundwater locations

\begin{tabular}{|c|c|c|}
\hline ID & WQI & Water Type \\
\hline S1 & 274 & Very Poor water \\
\hline S2 & 287 & Very Poor water \\
\hline S3 & 113 & Poor water \\
\hline S4 & 66 & Good water \\
\hline S5 & 4295 & Water unsuitable for drinking \\
\hline S6 & 83 & Good water \\
\hline S7 & 44 & Excellent water \\
\hline S8 & 52 & Good water \\
\hline S9 & 55 & Good water \\
\hline S10 & 46 & Excellent water \\
\hline S11 & 60 & Good water \\
\hline S12 & 96 & Good water \\
\hline S13 & 54 & Good water \\
\hline S14 & 59 & Good water \\
\hline S15 & 80 & Good water \\
\hline S16 & 40 & Excellent water \\
\hline
\end{tabular}

Table 6. Summary statistics of effective weight values for each water quality parameter

\begin{tabular}{|c|c|c|c|c|}
\hline \multirow{2}{*}{ Parameters } & \multicolumn{4}{|c|}{ Effective weight (\%) } \\
\cline { 2 - 5 } & Minimum & Maximum & Mean & $\begin{array}{c}\text { Standard } \\
\text { deviation }\end{array}$ \\
\hline $\mathrm{pH}$ & 0.03 & 15.58 & 4.30 & 3.98 \\
\hline $\mathrm{TDS}$ & 0.07 & 9.39 & 4.08 & 2.42 \\
\hline $\mathrm{TH}$ & 0.09 & 8.99 & 3.83 & 2.47 \\
\hline Turb & 0.02 & 4.77 & 0.65 & 1.14 \\
\hline $\mathrm{SO} 4-2$ & 0.03 & 25.06 & 3.47 & 5.92 \\
\hline $\mathrm{Cl}-$ & 0.08 & 16.49 & 5.25 & 4.31 \\
\hline $\mathrm{NO}-$ & 0.13 & 10.98 & 3.70 & 3.17 \\
\hline $\mathrm{F}-$ & 0.04 & 18.12 & 4.07 & 4.41 \\
\hline $\mathrm{Na}+$ & 0.02 & 4.45 & 1.88 & 1.57 \\
\hline $\mathrm{Cu}$ & 0.00 & 0.08 & 0.04 & 0.02 \\
\hline $\mathrm{Zn}$ & 0.00 & 0.05 & 0.02 & 0.01 \\
\hline $\mathrm{Pb}$ & 0.18 & 19.71 & 11.16 & 5.75 \\
\hline $\mathrm{Fe}$ & 0.00 & 1.03 & 0.36 & 0.27 \\
\hline $\mathrm{Mn}$ & 0.01 & 0.67 & 0.38 & 0.20 \\
\hline $\mathrm{Cr}$ & 0.18 & 19.71 & 11.16 & 5.75 \\
\hline $\mathrm{E} . \mathrm{coli}$ & 13.56 & 99.12 & 45.65 & 26.13 \\
\hline & & & &
\end{tabular}


7.94\% Table 2. On the other hand, the parameters $\mathrm{Cu}, \mathrm{Zn}, \mathrm{Fe}, \mathrm{Mn}$ and turbidity showed low mean effective weight values. These observations are primarily due to the measured concentration values of these parameters in water samples in comparison to their maximum allowable limit values, as prescribed in the JS286. As shown in the previous section, E.coli count exceeded the maximum allowable limit in all the studied locations with relatively high values observed at the sampling locations S1, S2, S3 and S5. This explains the high WQI values obtained in these four locations and contributes mainly to their water quality degradation (classified as Very poor water, Very poor water, Poor water and Water unsuitable for drinking, respectively). Additionally, the $\mathrm{Cr}$ and $\mathrm{Pb}$ concentration values are found comparable to their maximum allowable limit values in all the studied locations (i.e $<0.05 \mathrm{mg} / \mathrm{L}$ and $<0.01 \mathrm{mg} / \mathrm{L}$, respectively). On the other hand, $\mathrm{Cu}, \mathrm{Zn}, \mathrm{Fe}, \mathrm{Mn}$ and turbidity parameters showed very low concentrations in water samples compared to their maximum allowable limit values in all studied locations.

When E.coli count is not taken into account for the calculation of the WQI of the groundwater at each sampling location, the computed WQI values are between 29 and 90, Table 7. Thus, the groundwater quality can be categorized into two classes "excellent water" and "good water". It is evident from the results that out of 16 studied locations, 14 locations are classified in

Table 7. Results of water quality index for drinking purposes of the studied groundwater locations when E.coli count is not included in calculation

\begin{tabular}{|c|c|c|}
\hline ID & WQI & Water Type \\
\hline S1 & 40 & Excellent water \\
\hline S2 & 45 & Excellent water \\
\hline S3 & 50 & Excellent water \\
\hline S4 & 43 & Excellent water \\
\hline S5 & 41 & Excellent water \\
\hline S6 & 40 & Excellent water \\
\hline S7 & 34 & Excellent water \\
\hline S8 & 42 & Excellent water \\
\hline S9 & 46 & Excellent water \\
\hline S10 & 36 & Excellent water \\
\hline S11 & 51 & Good water \\
\hline S12 & 90 & Good water \\
\hline S13 & 43 & Excellent water \\
\hline S14 & 36 & Excellent water \\
\hline S15 & 37 & Excellent water \\
\hline S16 & 29 & Excellent water \\
\hline
\end{tabular}

the 'excellent water' class and two locations as a "good water" class. Moreover, the WQI without including E.coli count exhibited lower values than the WQI with including E.coli count in all studied locations even for those locations the water quality type stay at the same class (S7, S10 and S16 locations for excellent water class and S11 and S12 locations for good water class). The results from Table 5 and Table 7 firmly evidence that E.coli count parameter is considered as the most effective parameter in the WQI values. These results also clearly declare the importance of including microbiological parameters in any drinking water assessment since they reflect, with other physical and chemical parameters, the actual condition of water quality for different purposes. Therefore, proper actions on groundwater quality management can be initiated.

\section{CONCLUSIONS}

In this paper, the suitability for drinking purposes of groundwater in major groundwater basins in Jordan is investigated. The groundwater quality data from sixteen sampling stations within one-year-monitoring period from March 2015 to February 2016 were used. Weighted arithmetic WQI with the respect to the JS286 was used for quality assessment. Sixteen physical, chemical and microbiological parameters were selected to calculate WQI. The conclusions of this research can be summarized as follows:

- All physical and chemical parameters are almost below the maximum allowable level based on JS286.

- The microbiological parameter (i.e. E.coli count) exceeded the maximum allowable limit in all the studied locations based on JS286.

- The computed WQI values range from 40 to 4295. Therefore, out of the 16 studied locations, three locations are classified in the "Excellent water" class, nine locations as a "Good water" class, one as a "Poor water" class, two as a "very poor water" class, and one as a "water unsuitable for drinking purpose" class.

- According to effective weight values, E. coli is considered the most effective parameter in the WQI values in this study. This result is also confirmed by comparing the WQI value without including and including the E.coli count parameter. This result highlighted the importance of including microbiological parameters in any drinking water assessment. 


\section{Acknowledgments}

The author would like to thank the Ministry of Environment in Jordan for providing the required water quality data.

\section{REFERENCES}

1. Abbasi, T., \& Abbasi, S. A. 2012. Water Quality Indices (1st Editio). Elsevier. DOI:10.1016/ B978-0-444-54304-2.00001-4

2. Abbasnia, A., Yousefi, N., Mahvi, A. H., Nabizadeh, R., Radfard, M., Yousefi, M., \& Alimohammadi, M. 2018. Evaluation of groundwater quality using water quality index and its suitability for assessing water for drinking and irrigation purposes: Case study of Sistan and Baluchistan province (Iran). Human and Ecological Risk Assessment: An International Journal, 0(0), 1-18. DOI:10.1080/10807039.2018.1458596

3. APHA 2005. Standard Methods for the Examination of Water and Wastewater (21st editi). Washington, DC: American Public Health Association.

4. Asadollahfardi, G. 2015. Water Quality Management Assessment and Interpretation (1st ed.). Springer-Verlag Berlin Heidelberg. DOI:10.1007/978-3-662-44725-3

5. Barakat, M. A. 2011. New trends in removing heavy metals from industrial wastewater. Arabian Journal of Chemistry, 4(4), 361-377. DOI:https:// doi.org/10.1016/j.arabjc.2010.07.019

6. Brown, R. M., McClelland, N. I., Deininger, R. A., \& Tozer, R. G. 1970. A Water Quality Index: Do We Dare?. Water Sewage Works, 117(10), 339-343.

7. Chowdhury, S., Mazumder, M. A. J., Al-Attas, O., \& Husain, T. 2016. Heavy metals in drinking water: Occurrences, implications, and future needs in developing countries. Science of The Total Environment, 569-570, 476-488. DOI:https://doi. org/10.1016/j.scitotenv.2016.06.166

8. Debels, P., Figueroa, R., Urrutia, R., Barra, R., \& Niell, X. 2005. Evaluation of Water Quality in the Chillán River (Central Chile) Using Physicochemical Parameters and a Modified Water Quality Index. Environmental Monitoring and Assessment, 110(13), 301-322. DOI:10.1007/s10661-005-8064-1

9. Dede, O. T., Telci, I. T., \& Aral, M. 2013. The Use of Water Quality Index Models for the Evaluation of Surface Water Quality : A Case Study for Kirmir Basin, Ankara , Turkey. Water Qual Expo Health, 5, 41-56. DOI:10.1007/s12403-013-0085-3

10. El-Naqa, A., \& Al-Shayeb, A. 2009. Groundwater Protection and Management Strategy in Jordan. Water Resources Management, 23(12), 23792394. DOI:10.1007/s11269-008-9386-x
11. Freeze, A., \& Cherry, J. 1979. Groundwater. Prentice-Hall, Englewood Cliffs.

12. Horton, R. K. 1965. An index number system for rating water quality. Journal of Water Pollution Control Federation, 37(3), 300-306.

13. JS. 2015. Jordanian Standard 286/2015 on Water/ Drinking Water. Jordan Standards and Metrology Organization, Amman, Jordan.

14. Kannel, P. R., Lee, S., Lee, Y.-S., Kanel, S. R., \& Khan, S. P. 2007. Application of Water Quality Indices and Dissolved Oxygen as Indicators for River Water Classification and Urban Impact Assessment. Environmental Monitoring and Assessment, 132(13), 93-110. DOI:10.1007/s10661-006-9505-1

15. Kumar, S. K., \& Chandrasekar, N. 2012. Hydrogeochemical study of shallow carbonate aquifers, Rameswaram Island, India. Environ MonitAssess, 184, 4127-4138. DOI:10.1007/s10661-011-2249-6

16. Loizidou, M., \& Kapetanios, E. G. 1993. Effect of leachate from landfills on underground water quality. Science of The Total Environment, 128(1), 69-81. DOI:https://doi. org/10.1016/0048-9697(93)90180-E

17. Lumb, A., Sharma, T. C., \& Bibeault, J.-F. 2011. A Review of Genesis and Evolution of Water Quality Index (WQI) and Some Future Directions. Water Quality, Exposure and Health, 3(1), 11-24. DOI:10.1007/s12403-011-0040-0

18. Lumb, A., Sharma, T. C., Bibeault, J.-F., \& Klawunn, P. 2012. A Comparative Study of USA and Canadian Water Quality Index Models. Water Quality, Exposure and Health, 3(3-4), 203-216. DOI: $10.1007 /$ s12403-011-0056-5

19. Magesh, N. S., \& Chandrasekar, N. 2013. Evaluation of spatial variations in groundwater quality by WQI and GIS technique: a case study of Virudunagar District, Tamil Nadu, India. Arab J Geosci, 6, 1883-1898. DOI:10.1007/s12517-011-0496-Z

20. MoE. 2016. National Project for Monitoring Water Quality in Jordan: Annual report 2015-2016. Ministry of Environment (MOE). Amman, Jordan. Retrieved from http://moenv.gov.jo/AR/Documents/

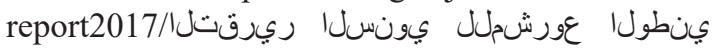
2015-2016.pdf

21. MWI/NWMP 2004. National Water Master Plan (NWMP). Ministry of Water and Irrigation (MWI), Amman, Jordan.

22. MWI 2002. Jordan's Water Strategy and Policies. Ministry of Water and Irrigation (MWI), Amman, Jordan.

23. MWI 2015. Jordan Water Sector Facts \& Figures 2015. Ministry of Water and Irrigation. Ministry of Water and Irrigation (MWI), Amman, Jordan.

24. Nagarajan, R., Rajmohan, N., Mahendran, U., \& Senthamilkumar, S. 2010. Evaluation of ground- 
water quality and its suitability for drinking and agricultural use in Thanjavur city, Tamil Nadu, India. Environ Monit Assess, 171, 289-308. DOI:10.1007/s10661-009-1279-9

25. Pesce, S. F., \& Wunderlin, D. A. 2000. Use of water quality indices to verify the impact of Cordoba City (Argentina) on Suquia River. Water Resour, 34(11), 2915-2926.

26. Ponsadailakshmi, S., Sankari, S. G., Prasanna, S. M., \& Madhurambal, G. 2018. Evaluation of water quality suitability for drinking using drinking water quality index in Nagapattinam district, Tamil Nadu in Southern India. Groundwater for Sustainable Development, 6 (October 2017), 43-49. DOI:10.1016/j.gsd.2017.10.005

27. Sahu, P., \& Sikdar, P. K. 2008. Hydrochemical framework of the aquifer in and around East Kolkata Wetlands, West Bengal, India. Environmental Geology, 55(4), 823-835. DOI:10.1007/s00254-007-1034-X

28. Sawyer, C.N., McCarty, P.L., \& Parkin, G.F. 2003. Chemistry for Environmental Engineering and Science (5th Ed.). Boston: McGraw-Hill Education.

29. Şener, Ş., Şener, E., \& Ayşen Davraz. 2017. Evaluation of water quality usingwater quality index (WQI) method and GIS in Aksu River (SW-Turkey). Science of the Total Environment, 585, 131-
144. DOI:10.1016/j.scitotenv.2017.01.102

30. Sujatha, D., \& Reddy, B. R. 2003. Quality characterization of groundwater in the south-eastern part of the Ranga Reddy district, Andhra Pradesh, India. Environmental Geology, 44, 579-586. DOI:10.1007/s00254-003-0794-1

31. Sutadian, A.D., Muttil, N., Yilmaz, A.G., \& Perera, B.J.C. 2016. Development of river water quality indices - a review. Environmental Monitoring and Assessment, 188: 58. DOI: $10.1007 / \mathrm{s} 10661-015-5050-0$.

32. WHO. 1996. Guidelines for drinking water quality, Volume 2, Health Criteria and Other Supporting Information (2nd Ed., Vol. 1). Geneva, Switzerland: World Health Organization (WHO).

33. WHO 2006. Establishing National Drinking-Water Standards. Guidelines for drinking-water quality training pack. Retrieved August 12, 2018, from http://www.who.int/water_sanitation_health/dwq/ S17.pdf

34. WHO 2011a. Guidelines for drinking-water quality (fourth edi). Geneva: World Health Organization (WHO).

35. WHO 2011b. Hardness in drinking-water. Background document for preparation of WHO Guidelines for drinking-water quality. Geneva: World Health Organization. 